\title{
Preliminary Phytochemical Screening, Elemental and Proximate Composition of Two Varieties of Cyperus esculentus (Tiger Nut)
}

\author{
${ }^{* 1}$ T.S. Imam, ${ }^{1}$ F.G. Aliyu and ${ }^{2}$ H.F. Umar \\ 1Biological Sciences Department, Bayero University, Kano, PMB 3011, Kano, Nigeria \\ 2Department of Pure and Applied Chemistry, Bayero University, Kano, PMB 3011, Kano, \\ [Corresponding Author, E-mail: tijianimam70@gmail.com, 罣: +2348133382562]
}

\begin{abstract}
The study aimed at phytochemical screening, elemental and proximate composition of two varieties of Cyperus esculentus (tiger nut) big yellow and small brown nuts using standard methods. The phytochemicals tested for were alkaloid, saponin, tannin, glycoside, flavonoid, steroid and resin. All the aforementioned phytochemicals with the exception of resin were present in the two varieties. The elements tested for were $\mathrm{Na}, \mathrm{Ca}$, $\mathrm{Mg}, \mathrm{Mn}, \mathrm{Zn}, \mathrm{K}$ and $\mathrm{Fe}$. The result shows big yellow variety had higher $\mathrm{Na}, \mathrm{K}$, and $\mathrm{Ca}$ with mean values 70.8 $\mathrm{mg} / \mathrm{Kg}, 3694.43 \mathrm{mg} / \mathrm{Kg}$ and $372.2 \mathrm{mg} / \mathrm{Kg}$ respectively. Both samples had equal $\mathrm{Fe}, \mathrm{Zn}$ and $\mathrm{Mn}$ contents of 21.0 $\mathrm{mg} / \mathrm{Kg}, 8.3 \mathrm{mg} / \mathrm{Kg}$ and $1.67 \mathrm{mg} / \mathrm{Kg}$ respectively. Small brown variety had higher $\mathrm{Mg}$ content $(308.3 \mathrm{mg} / \mathrm{Kg})$. The proximate analysis show brown yellow variety had higher ash, crude protein and crude fiber contents with values of $1.85 \%, 2.75 \%$ and $9.25 \%$ respectively. While small brown variety had higher moisture and fatty acid contents of $4.25 \%$ and $15.2 \%$ respectively. Considering the potential nutritive and health benefits of the underutilized tiger nuts, it is suggested that utilization of tiger nut products (such as biscuits, flour and milk etc.) should be encouraged so as to ameliorate the problem of protein-calorie malnutrition in children, since it is rich in nutritional contents.
\end{abstract}

Keywords: Cyperus esculentus, elemental, phytochemical, proximate, tiger nut

\section{INTRODUCTION}

Tiger nut is a grass-like plant of the Family Cyperaceae (sedge family), Order Cyperales or Graminales (Takhatajah, 1992). Like other sedges, the plant is most frequently found inhabiting wet marshes and edges of streams and ponds where it grows in coarse turfs (Saxena, 2001).

In Nigeria, the Hausas call it "Aya", Yorubas "Imumu" the Igbos "Ofio", or "aki Hausa" in southern Nigeria (Oladele et al., 2009). Tiger nut has many other common names which include, Zulu nut, yellow nut grass, ground almond, Chufa, edible rush, rush nut, duck potato etc (Oladele et al., 2009).

In Nigeria, tiger nut is well grown in the middle belt and northern region (Oladele et al., 2009), where it is sold locally and consumed uncooked. In Spain, the tubers are consumed mainly as a drink called "horchata de chufa" (Chufa Milk). It has been cultivated as a livestock food and for human consumption (Umerie et al., 1997). According to Belewu and Abodunrin (2006), three varieties are cultivated i.e. yellow, brown and black. Among these only two varieties; yellow and brown are readily available in Nigeria market (Omode et al., 1995).

The medicinal benefits of tiger nuts are ascribed to a large number of nutritional components or constituents it contains. Sugar free tiger nut milk is suitable for diabetic patients (Anon, 1992). They are thought to be beneficial to those seeking to reduce cholesterol or lose weight (Beniwal, 2004). It is good for arteriosclerosis (Mohammad et al., 2005).

According to Stern et al., (2003) Paiute Indians pound tiger nut tubers with tobacco leaves applied en masse on wet dressing for treatment of athlete's foot. Tiger nut milk is used in making soap and bath milk due to its high content of vitamin E, (Tiger Nut and Health, 2013). Chufa tubers can be used for the production of alcohol by fermentation (Des-Vries, 1991). Roasted tubers are used as a coffee substitute (Oderinde and Tahir, 1988). The oil of tiger nut (C. esculentus) is used for the production of biodiesel (Nag, 2008).

The research for lesser known and underutilized crops, which include tiger nuts, many of which are potentially valuable as human and animal food has been intensified to maintain a balance between population growth and agricultural productivity particularly in tropical and sub-tropical areas of the world (FAO, 1985).

This study is aimed at preliminary phytochemical screening, elemental and proximate analysis of two varieties of Cyperus esculentus (tiger nut). 


\section{MATERIALS AND METHOD}

\section{Collection and Identification of Sample}

The two varieties of Cyperus esculentus (yellow and brown) were collected from markets in Katsina, Kaduna, Bauchi and Kano states in Nigeria. The Samples were identified according to the identification protocols of Dutta (2011). Samples were coded BY (big yellow) and SB (small brown) after sorting them based on their colour and relative size.

\section{Preparation of Sample}

The tubers were thoroughly screened to remove the bad ones and stones. The tubers were later washed, drained and air- dried. The samples were ground using wooden mortar and pestle until a fine powder was obtained to ensure homogeneity. The powdered sample was passed through a fine (2mm mesh) sieve to remove any remaining residue. The fine powdered sample was then stored into labeled plastic containers.

\section{Preparation of Plant Extract}

Aqueous extract of each sample was prepared by soaking $100 \mathrm{~g}$ of dried powdered sample in $200 \mathrm{ml}$ of distilled water for 24 hours. The extracts were filtered using whatman filter paper No.42 (125mm) (Edeoga et al.,2005).

\section{Preliminary Qualitative and Quantitative Phytochemical Screening}

The aqueous extracts were analyzed for alkaloids, glycosides, flavonoids and resins as described by ElMahmood and Dhoughari, (2008); test for reducing sugar was carried out as described by Trease and Evans (1989); while tests for saponins, tannins and steroids were conducted as described by Hassan et al. (2005).

\section{Proximate Composition Analysis}

The samples were subjected to proximate analysis to determine the moisture, ash, crude fiber, crude protein and nitrogen using the standard method of the Association of Official Analytical Chemists, AOAC (2003).

\section{Drying, Ashing, Digestion and Determination of Elemental Concentrations}

The samples after drying and grounding, $1 \mathrm{~g}$ of the powdered sample was spread in porcelain dish and placed in muffle furnace. The ash sample was digested using $6 \mathrm{~N} \mathrm{HCl}$. Analysis of $\mathrm{Na}, \mathrm{K}$ and $\mathrm{Ca}$ was carried out using atomic absorption spectrophotometer (AAS) (APHA, 2005).

\section{Statistical Analysis}

SPSS version 15.0 statistical software was used to compute data for statistical significance. The data obtained were analyzed for descriptive (i.e. mean, sum, standard deviation), Chi-squared test in order to test for the significance at $P \leq 0.05$ between varieties.

\section{RESULTS AND DISCUSSION}

The physical properties of the aqueous extract of the phytochemical screening of the two varieties of Cyperus esculentus are presented in Table 1. C. esculentus, as shown in Table 2 show that the small brown variety has higher alkaloid, saponin, flavonoid, glycoside, than the big yellow variety. While the big yellow variety has higher tannin, steroid and reducing sugar. Resin is absent in both samples (Table 3). The absence of resin in C. esculentus in the present study is in contrast with the opinion of Gills (1992). The absence may be due to differences in soil composition, amount of rainfall, leaching effect, climate and type of manure used. Saponins have been reported to be useful in reducing inflammation of the upper respiratory passage (Frantisek, 1991). Alkaloids are known for their toxicity but not all Alkaloids are toxic. They inhibit certain mammalian enzymes and are also known to affect glucagon and thyroid stimulating hormones (Okaka et al., 1991). Steroids are of importance and interest in pharmacy due to their relationship with such compounds as sex hormones (Okwu, 2001). Tannins have astringent properties that hasten the healing of wounds and prevention of decay. Glycosides help modify biologically activity by helping to strengthen contraction of the heart muscle (Frantisek, 1991). The phytochemicals obtained from the tuber posses some biological active compounds which could serve as potential source of vegetable drugs in herbal medicine.

The current study show that the big yellow nut has higher calcium, potassium, and sodium contents with values $372.2 \mathrm{mg} / \mathrm{kg}, 36940.43 \mathrm{mg} / \mathrm{kg}$ and $70.8 \mathrm{mg} / \mathrm{kg}$ respectively, but with lower manganese content $(1.67 \mathrm{mg} / \mathrm{kg})$ (Table 4). The presence of potassium and calcium in tiger nut are adequate for bone and teeth development in infants (Chevalier, 1996). The small brown nut has higher concentration of magnesium than the big brown variety. The presence of other minerals such as iron is highly important because of its requirement in blood formation, almost two-third of Fe 
in the body is found in haemoglobin which helps in carrying oxygen to tissues (National Institute of Health, 2013). The World Health Organization considers Fe deficiency as number one nutritional disorder in the world (CDC, 1998). The proximate composition of food is a major index of nutritious potentials of crops. The analysis show higher carbohydrate and crude fibre contents in the big yellow nut than in the small brown variety (Table 5). But, moisture and fatty acid contents are higher in the small brown nut than in the big yellow variety although not significant $(P>0.05)$.

Table 1: Physical Properties of Aqueous Extract of Two Varieties of C. esculentus

\begin{tabular}{lllll}
\hline Sample ID & Color & Taste & Texture & Odour \\
\hline BY1 & light brown & Sugary & clear with suspension & nutty \\
BY2 & light brown & Sugary & clear with suspension & nutty \\
BY3 & light brown & Sugary & clear withsuspension & nutty \\
SB1 & dark brown & slightly sugary & slightly clearwith suspension & nutty \\
SB2 & dark brown & slightly sugary & slightly clear with suspension & nutty \\
SB3 & dark brown & slightly sugary & slightly clearwith suspension & nutty \\
\hline BY1 = big yellow from Kaduna & BY2 = big yellow from Katsina & BY3 = big yellow from Kano & \\
SB1 = small brown from Kaduna & SB2 = small brown from Katsina & SB3 = small brown from Kano &
\end{tabular}

Table 2: Preliminary Qualitative Phytochemical Screening of Aqueous Extract of $C$. esculentus Varieties

\begin{tabular}{ccccccccc}
\hline Sample ID & Alk & Tan & Sap & Gly & Flav & Ste & R/S & Res \\
\hline BY1 & ++ & +++ & ++ & ++ & ++ & +++ & +++ & - \\
BY2 & ++ & +++ & ++ & ++ & ++ & +++ & +++ & - \\
BY3 & ++ & +++ & ++ & ++ & ++ & +++ & +++ & - \\
SB1 & +++ & ++ & +++ & +++ & +++ & ++ & ++ & - \\
SB2 & +++ & ++ & +++ & +++ & +++ & ++ & ++ & - \\
SB3 & +++ & ++ & +++ & +++ & +++ & ++ & ++ & - \\
\hline
\end{tabular}

Alk=Alkaloid; Tan=Tannin; Sap=Saponin; Gly=Glycoside; Flav=Flavonoid Ste=Steroid; R/S=Reducing sugar; Res=Resin

- = not present; + = present at trace amount; ++ = present at low amount; +++ = present at moderate amount; ++++ = present at high amount

Table 3: Preliminary Quantitative in mg/g Phytochemical Screening of Aqueous Extract of Two C. esculentus Varieties

\begin{tabular}{lcccc}
\hline Sample ID & Alkaloid & Glycoside & Tannin & Flavonoid \\
\hline BY & $0.34 \pm 0.20$ & $0.47 \pm 0.002$ & $0.45 \pm 0.07$ & $0.23 \pm 0.001$ \\
SB & $0.45 \pm 0.01$ & $0.48 \pm 0.002$ & $0.27 \pm 0.07$ & $0.27 \pm 0.001$ \\
\hline
\end{tabular}

The values in the table are Mean \pm SD from duplicate determinations, there was no significant difference at $p \leq 0.05$.

Table 4: Elemental Composition in $\mathrm{mg} / \mathrm{kg}$ dry weight of Cyperus esculentus

\begin{tabular}{cccccccc}
\hline Sample ID & $\mathrm{Na}$ & $\mathrm{K}$ & $\mathrm{Mg}$ & $\mathrm{Mn}$ & $\mathrm{Ca}$ & $\mathrm{Fe}$ & $\mathrm{Zn}$ \\
\hline BY & $70.8 \pm 3.19$ & $3694.43 \pm 127.29$ & $283.3 \pm 38.17$ & $1.67 \pm 1.45$ & $372.2 \pm 78.77$ & $21.0 \pm 2.85$ & $8.3 \pm 2.62$ \\
SB & $65.07 \pm 8.79$ & $2750.0 \pm 166.7$ & $308.3 \pm 14.43$ & $1.67 \pm 1.45$ & $273.9 \pm 57.38$ & $21.0 \pm 2.85$ & $8.3 \pm 2.62$ \\
\hline
\end{tabular}

The values in the table are Mean \pm SD from triplicate determinations. There was significant difference at $p \leq 0.05$ using $X^{2}$ test.

Table 5: Proximate Analysis (\%) of Cyperus esculentus

\begin{tabular}{cccccccc}
\hline Sample ID & Ash & Moisture & DM & CP & CF & CHO & F/acid \\
\hline BY & $1.85 \pm 0.15$ & $3.75 \pm 0.25$ & $96.25 \pm 0.25$ & $2.75 \pm 0.25$ & $9.25 \pm 0.25$ & $68.15 \pm 0.85$ & 7.40 .55 \\
SB & $1.25 \pm 0.25$ & $4.25 \pm 0.25$ & $95.75 \pm 0.35$ & $2.50 \pm 0.02$ & $8.95 \pm 0.25$ & $67.85 \pm 0.75$ & $7.6 \pm 0.62$
\end{tabular}

The values in the table are Mean \pm SD from duplicate determinations. There was no significant difference at $p \leq 0.05$ using $X^{2}$ test.

$\mathrm{KEY}$ : $\mathrm{ASH}=A$ shing; $\mathrm{DM}=$ dry matter; $\mathrm{CP}=$ crude protein; $\mathrm{CF}=$ crude fibre, $\mathrm{CHO}=$ carbohydrate; f/acid =fatty acid 
The moisture content of the two varieties decreased appreciably due to their dry state or climatic condition. The ash content value of $\mathrm{C}$. esculentus of $1.85 \%$ and $1.25 \%$ for both big yellow and small brown varieties respectively was within the range of $1.5-2.5 \%$ reported by Sofowora (1993). The fat content is within the range reported by Borges et al., (2008), which promotes fat soluble vitamin absorption. Tiger nut has high fibre content, the consumption of significant quantities of $C$. esculentus would therefore not constitute a risk factor to some pathologic stages i.e diabetic mellitus, obesity and coronary heart disease. Past researches have linked low fibre content in the diet with health problems such as heart disorders, bowel cancer and appendicitis (Pyke, 1979).

\section{CONCLUSION}

It is noteworthy that both the two tiger nuts varieties (small brown and big yellow nuts) contain all the phytochemicals tested with the exception of resin. Essential elements such $\mathrm{Na}, \mathrm{K}, \mathrm{Mg}, \mathrm{Mn}, \mathrm{Ca}$, Fe and $\mathrm{Zn}$ were found in appreciable levels in both two varieties. Also other classes of food such as carbohydrate, protein, fatty acid, and fibre were present. Considering the nutritive and health benefits of the underutilized tiger nuts, there is the need for increased utilization and awareness of its health benefits.

\section{RECOMMENDATIONS}

i. Government should encourage farmers towards large scale cultivation of tiger nut.

ii. Bakers should be introduced to the usage of tiger nut flour so as to reduce over-dependence on wheat flour.

iii. Cattle rearers or livestock farmers should be sensitized on feeding livestock with tiger nut seed meal base diet so as to improve feed efficiency and weight gain.

iv. Establishment of small scale industries to enhance the production of tiger nut oil, cosmetics, papermaking and mat production from tiger nut so as to boost economic development and reduce unemployment in the society.

v. Further research should be carried-out on the medicinal properties of the tuber.

\section{REFERENCES}

Anon, A. (1992). The New Encyclopedia Britannica, Macropaedia, Chicago, USA. 3(15): 185.
AOAC (2003). Official Methods of Analysis, Association of official Analytical Chemists, Washington, D.C., USA. pp $200-210$.

APHA (2005). Standard Methods for the Examination of Water and Wastewater. 21 ${ }^{\text {st }}$ edition, eds. Eaton, A.D., Clescer, L.S., Rice, E.N. and Greenberg, A.E. Port City Press, Baltimore, USA.

Belewu, M.A and Abodunrin, O.A. (2006). Preparation of Kunnu from Unexploited abounding food source (tigernut), World Journal of Dairy and Food Science, 1: 19-21.

Beniwal, R.S. (2004). A randomized trial of Yoghurt for prevention of antibiotic associated diarrhea, Digestive Disease Science. 48: 2077-2082.

Borges, O., Goncalves, B., Segeoiro, I. and Silva, A. (2008). Nutritional Quality of Chestnut Cultivars From Portugal. Food Chemistry, 106(3): 976-984.

CDC (1998). CDC Recommendations to Prevent and Control Fe Deficiency in the US. Centre for Disease Control and Prevention. MMWR Rep. 47:1-29.

Chevalier, A. (1996). The Encyclopaedia of Medicinal Plants, Dorling, Kindersley Press, London, pp: 4851.

Des- Vries, F.T. (1991). Chufa (C. esculentus) a Weedy Cultivar and Cultivated Weed, Economic Botany. 45: 27-37.

Dutta, A. C. (2011). Botany for Degree Students. $6^{\text {th }}$ edition, India, Oxford Univ. Press. pp: 529-595.

Edeoga, H.O., Okwu, D.E. and Mbaebie, B.O. (2005). Phytochemical Constituent of Some Nigerian Medicinal Plants. African Journal of Biotechnology, 4(7): 685-688.

El-mahmood, A.M. and Doughari, J.H. (2008). Phytochemical screening and antibacterial evaluation of the leaf and roots extracts of Cassia slata L. African Journal of Pharmacology, 2(7):124129.

FAO, (1985). Expert consultation, Energy and Protein Requirements, WHO, Geneva.

Frantisek, S.S. (1991). The Natural Guide to Medicinal Herbs And Plants. Tiger Barks Cast. Twinkemhan, United Kingdom. pp 1-5.

Gills, L.S. (1992). Ethnomedical Uses of Plants in Nigeria,University of Benin Press, Nigeria. pp 276.

Hassan, M.M., Oyewale, Amupitan A.O, Abdullahi, I.O Abdullahi M.S and Okonkwo, E.M. (2005). Preliminary Phytochemical and Antibacterial Investigation of the Root bark of Deterium microcarpum, Journal of Chemical Society of Nigeria, 29(1): 26-29. 
Mohammad, L.S., Mohsen, Z. and Imaizumi, K. (2005). Dietary Supplementation with Cyperus esculentus (tigernut) tuber attenuated atherosclerotic lesion In apoliprotein with knock-out mouse associated with inhibition of Inflammation cell responses. American Journal of Immunology, 1(1): 60-67.

Nag, A. (2008). Bio-fuels Refining and Performance, Mc Graw-Hill Professional USA. pp.127-128.

National linstitute of Health (2013). Dietary supplement Fact Sheet: Iron. Retrieved from http://ods.od.nih.gov/factsheet//ron_Health Professional. accessed on 23/01/2013.

Oderinde, R.A. and Tahir, O.A. (1988). Chemical investigation of Nigerian Cyperus esculentus tuber the possible industrial application. Nigerian Journal of Science, 22: 70-73.

Okaka, J.C., Enoch, N.J. and Okaka, N.C. (1991). Human Nutrition: An Integrated Approach, ESUT publications, pp 57-58.

Okwu, D.E. (2001). Evaluation of The chemical composition of indigenous species and Flavouring Agents. Global Journal of Pure and Applied Science. 7(3): 455-459.

Oladele, K.A. and Osundahunsi, F.O. and Adebowale, A.Y. (2009). Influence of processing techniques on the Nutrients and Anti-nutrients of tiger nut $(C$. esculentus), World Journal of Diary and Food Science, 2: 88-93.

Omode, A., Fatoki, A. and Olaogun, K.A. (1995). Physiochemical properties Some under-exploited and non-conventional oil seed, Journal of Agricultural Food Chemistry, 11: 50-53.

Pyke, M. (1979). Success in Nutrition. Revised edition, Richard Clay Ltd, Suffolk, UK, pp: 29-32.

Saxena,O.P.(2001). Plant Taxonomy, $3^{\text {rd }}$ edition, Educational Publishers, Meerut, India. pp. 505-506.

Sofowora, A. (1993): Medicinal plants and Traditional medicine in Africa. Spectrum Books Ltd, Ibadan, Nigeria. pp. 289.

Stern, K. R., Jonsky, S. and Bidlack, E. J. (2003). Introductory Plant Biology, 9th edition, Mc GrawHill, USA pp. 569.

Takhatajah, A. (1992). Angiosperms (the flowering plants) New Encyclopedia Britannica, macropedia, 13(15): 596-610.

Tiger Nut and Health (2013). Health Tigernuts. Retrieved on 23/01/2013 from www.tigernuts.com/ tiger health.html

Trease, G.E. and Evans, W.C. (1989). Pharmacognsy. $11^{\text {th }}$ edition, Brailliar

Umerie, S.C., Okafor, E.P. and Uka, A. J. (1997). Evaluation of Tubers and Oil of Tiger Nuts. Bioresources Technology, 61: 171-173. 